\title{
SEPARATION OF POWERS IN UKRAINE: CHALLENGES AND SOLUTIONS FROM THE ADMINISTRATIVE LAW PERSPECTIVE
}

Separation of powers has been considered as one of the main pillars of any democratic state. There are different schools of thought regarding the content and the role of the separation of powers for the democratic government, from the "pure" traditional theory of the strict separation of powers to the flexible modern approach. In Ukraine, the principle of separation of powers is stipulated by the Constitution of Ukraine. Some professionals believe that only bodies of legislative, executive and judicial power can be established in Ukraine, whilst others argue the existence of independent bodies that do not belong to any branch of power. This paper aims to explore the challenges for the implementation of the principle of separation of powers in Ukraine in relation to the system of public administration and to outline the possible solutions for the enhancement of the legal status of the public administration entities. Methods. The goal of the paper has been met due to use of modern methods of legal research, in particular, the method of logical analysis, system-structural, and structure-functional methods.

Results. It is suggested to distinct a branch of power and a branch of government, as functional and institutional elements of the principle of the separation of powers.

Conclusions. It is concluded that there are public authorities that formally do not belong to any branch of power, in particular, National Bank of Ukraine, national regulatory commissions, Central Election Commission, State Security Service, National Anticorruption Bureau of Ukraine. Despite the recent changes to the Constitution of Ukraine, the issue regarding the place in the system of public authorities of the public prosecutor's office needs to be addressed. It is concluded that the National agency for quality assurance in higher education does not have a status of a public authority, despite the executing some functions of a body of executive power.

With regards to the national regulatory commissions and National anticorruption bureau of Ukraine it is necessary to amend the Constitution of Ukraine with the provisions regarding such authorities, in particular, with the powers of the President of Ukraine and the Verkhovna Rada of Ukraine in relation to these authorities.

Key words: separation of powers, executive branch of power, branch (field) of government, public administration, independent regulatory authorities, forth branch of power. 


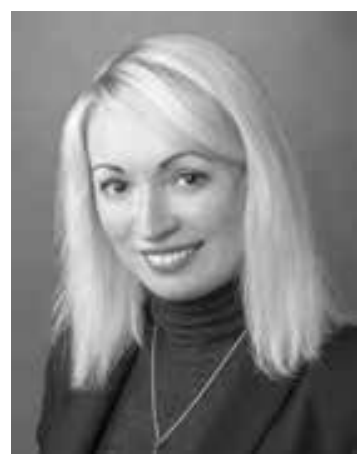

Yuliya Vashchenko, Professor at the Administrative Law Department, Faculty of Law, Taras Shevchenko National University of Kyiv, Dr. Habil. (Law), Docent orcid.org/0000-0002-5252-1997 y_vashchenko@univ.kiev.ua

\section{Introduction}

Separation of powers has been considered as one of the main pillars of any democratic state. As an essential element of the rule of law, it is characterized as a political ideal to some extent. There are different schools of thought regarding the content and the role of the separation of powers for the democratic government, from the "pure" traditional theory of the strict separation of powers to the flexible modern approach. The approaches regarding the constitutionalization of this principle also differ all over the world. Each state decides on the structure of government, the system of bodies of legislative, executive, and judicial power, and the checks and balances mechanisms aim to prevent the abuse of power. However, the principle of separation of powers remains one of the core principles of the theory of constitutionalism despite of its legal footings and scientific debates.

One of the debated issues related to the principle of separation of powers is existence of bodies that do not belong to any traditional branches of power and separation of the forth branch of power. In particular, such debates have been conducted around the independent regulatory authorities that combine to certain extent the functions of all three branches of power (Vashchenko, 2015).

In Ukraine, the principle of separation of powers is stipulated by the Constitution of Ukraine. As referred to Article 6, the power in Ukraine is exercised on the basis of its separation into legislative, executive, and judicial power. Bodies of legislative, executive and judicial power carry out their powers within the scope of the Constitution and laws of Ukraine. Some professionals believe that only bodies of legislative, executive and judicial power can be established in Ukraine, whilst others argue the existence of independent bodies that do not belong to any branches of power or belong to another, nontraditional, branch of power (e. g., control branch of power).

Separation of powers is traditionally defined among the key principles of Constitutional law. National constitutions include provisions related the checks and balances mechanisms in the system of public authorities. Obviously, the issues of the separation of powers have been explored by the representatives of the Constitutional law science. However, the Administrative law science cannot stand off from these debates, in particular, considering the following arguments. The initiation and execution of the state policy - traditional functions of the executive branch of power - are among the 
core state functions. Thus, the executive branch of power plays a very important role in the state mechanism. The functions of the executive branch of power are carried out by a huge number of public authorities, mainly but not limited to the bodies of executive power. Legal relations in the area of executive branch of power belong to the subject of the Administrative Law. The issues whether it is possible to carry out the functions of the executive branch of power outside the hierarchy of the bodies of executive power should be discussed by the representatives of the Administrative law science. Since Administrative law has been considered as concretized Constitutional Law (Bignami, 2012), it is the Administrative law science that should suggest the appropriate legal regimes of accountability and liability of bodies that carry out the functions of executive branch of power. Following the approach to understanding Administrative law as a testing area of Constitutional law expressed by E. Schmidt-Assmann (Schmidt-Assmann, 2009), Administrative law science has to explore the legal nature of the independent authorities that do not belong to any branch of power and to provide theoretically proven recommendations regarding the enhancement of their legal status.

This paper aims to explore the challenges for the implementation of the principle of separation of powers in Ukraine in relation to the system of public administration and to outline the possible solutions for the enhancement of the legal status of the public administration entities.

The following objectives will support the main goal of this research:

1) to provide some reflections on the resent trends of the understanding the principle of the separation of powers;

2) to define the challenges for the implementation of the principle of separation of powers in the light of the recent developments of the system of public authorities in Ukraine;

3) to outline the possible solutions for the compliance with the principle of the separation of powers in Ukraine.

The goal of the paper has been met due to usage of modern methods of legal research, in particular, the method of logical analysis, system-structural, and structure-functional methods.

2. Understanding the principle of the separation of powers: some reflections of the recent trends

According to the classical or "pure" approach the principle of the separation of powers consists of the following elements:

- separation of the public authorities;

- separation of the functions;

- separation of the personnel.

In other words, one public authority can carry out functions of only one branch of power (e. g., legislative authority - functions of the legislative branch of power), and the personnel of a public authority that belong to one branch of power cannot combine the work in this authority with the work in the public authority belong to another branch of power.

However, this classical approach faces many critics in the recent years. The pure separation of powers seems to be a desirable, but not possible model of a modern governmental organization. 
In particular, A. Kavanaugh points out that the claim that there is a one-to-one correlation between function and branch is impossible to sustain in any modern state (Kavanagh, 2016).

As M. Magill argues that government authority is fragmented, widely so, albeit not according to the three-powers-in-three-branches formula. Instead, government authority is diffused among a large and diverse set of government decision makers who have a hand in the exercise of state power (Magill, 2001). In her vision, if diffusion of state authority is what we are after - and that is what conventional approaches in part are seeking - we have it. To the extent that separation of powers doctrine is driven by worries about the prospect of dangerous concentrations of state power in a single institution of government, those worries are misplaced (Magill, 2001).

$\mathrm{V}$. Shapoval points out that the content of public power is not limited to the responsibilities of legislative, executive and judicial authorities, even though these responsibilities constitute its basis. Eventually, he concluded that the placement and the role of certain public bodies and public officials in governing crucially depend on their powers, peculiarities of their competence connections with other public authorities (Shapoval, 2012).

It should be mentioned that the existence of the public authorities that cannot be placed within the systems of bodies belong to traditional branches of legislative, executive and judicial power is one of the serious arguments for the failure of the "pure" separation of powers. In particular, independent regulatory agencies that combine functions of all traditional branches of power (such called "quasi-legislative", "quasi-executive" and "quasi-judicial") have been considered as a challenge for the traditional understanding of the separation of power (Vashchenko, 2015). In some countries, public prosecutor's office, central banks, central election authorities have a special place in the system of public authorities and do not belong to any traditional branches of government. In particular, B. Toppetwien, while analyzing the issues of the separation of powers in Australia, suggests that Parliament and the executive can create, and effectively have created, a fourth arm of government, independent of, but subject to oversight by, Parliament, the executive, and the judiciary. This fourth arm, which exercises all three types of powers (executive, legislative and judicial), comprises those independent agencies of government that are not subject to direct Ministerial (i. e., executive) or Parliamentary control - including administrative tribunals, the Ombudsman Auditor-General, and numerous other similarly independent governmental instrumentalities and statutory office holders (Toppetwien, 1999).

Despite all critics of the "pure" approach mentioned above, the majority of scholars agree on the importance of the separation of powers, even though there is a lack of the consitutionalization of such principle in some countries. For example, J. Waldron points out that even when a principle lacks specific legal status, it still may be an indispensable part of our constitutionalism, an indispensable touchstone for evaluating the operation of and any change in our constitutional arrangements (Waldron, 2013). In his opinion, the failure of the separation of powers is not just that the powers are all in one set of hands; it is that the person who holds them does not even think to distinguish them (Waldron, 2013).

The shift in the discussions from the "pure" separation to the interconnection and mutual accountability of the public authorities belong to deferent branches of power should be noticed among recent scientific trends. In particular, A. Kavanagh mentions that many 
argue that some 'intermixture' of functions is both necessary and desirable. Scheme of checks and balances involves a degree of mutual supervision between the branches of government and, therefore, a degree of interference by one branch into the functions and tasks of the other (Kavanagh, 2016). While analyzing the three elements of the separation of powers mentioned above, the scholar stresses the importance of the separation of labour. He points out that instead of distinguishing the branches in terms of three mutually exclusive functions, we should think of the separation of powers as requiring a division of labour where each branch plays a distinct role in the constitutional scheme. Though the labour is divided, functions may be shared (Kavanagh, 2016).

In Ukraine, the principle of the separation of powers is constitutionalized. Thus, Article 6 of the Constitution of Ukraine stipulates that the power in Ukraine is exercised on the basis of its separation into legislative, executive, and judicial power. Bodies of legislative, executive and judicial power carry out their powers within the scope of the Constitution and laws of Ukraine. Some professionals believe that only bodies of legislative, executive and judicial power can be established in Ukraine, whilst others argue the possibility of the existence of bodies that do not belong to any branches of power or belong to another, nontraditional, branch of power. Despite the theoretical approaches to this matter, one can conclude that the bodies that enjoy special status in the system of public authorities and do not belong to any branches of power exist in Ukraine, based on the analysis provided below.

3. State collegial authorities in the system of public administration of Ukraine: obstacles to the principle of separation of powers?

The system of public administration in Ukraine has been increased of bodies with the special status - the state collegial authorities. First of all, the national commissions that conduct state regulation in certain fields of economics enjoy such status. Nowadays, there are the following independent regulatory authorities in Ukraine: National Energy and Utilities Regulatory Commission (hereinafter - the energy regulator), National Connection and Informatization Regulatory Commission, National Financial Services Markets Regulatory Commission, National Securities and Stock Market Commission. These bodies have been excluded from the system of bodies of executive power. The legal framework of such bodies is presented by special laws of Ukraine that regulate the relations in certain economic spheres, namely, by Law of Ukraine "On telecommunications" of 19 November 2003 No 1280-IV - for National Connection and Informatization Regulatory Commission, Law of Ukraine "On state regulation of stocks market in Ukraine" of 30 October 1996 No 44896-BP- for National Securities and Stock Market Commission, Law of Ukraine "On financial services and state regulation of financial services markets" of 12 July 2001 No 2664-III - for National Financial Services Markets Regulatory Commission, and by Law of Ukraine "On National Energy and Utilities Regulatory Commission" of 22 September 2016 No 1540-VIII - for the energy regulator.

All the authorities mentioned above have the status of the state collegial authorities and do not belong to the system of bodies of executive power. However, there are some differences in the establishment procedures and accountability regimes of such authorities. Thus, all the commissions have the status of state collegial authorities, but it is specified that the energy regulator has a status of the independent permanent state collegial 
authority. All the commissions consist of 7 persons; however, 6 members and a head of all commissions except the energy regulator are appointed and dismissed by the President of Ukraine. As to the energy regulator, the President of Ukraine appoints and dismisses all 7 members; the head of the commission shall be elected by the members. Also the members of the energy regulator shall be appointed by the President of Ukraine upon the recommendations of the special competition commission established in accordance with the Law on the energy regulator. All the commissions except the energy regulator are subordinated to the President of Ukraine and accountable to the Verhknovna Rada of Ukraine. As the energy regulator, it enjoys the status of an independent authority. There is no regime of subordination for such authority stipulated by the Law; however, it shall provide the annual report to the Verkhovna Rada of Ukraine.

It should be mentioned that by the present moment, these regulatory authorities are outside the constitutional framework in Ukraine since the Constitution of Ukraine does not define such type of state bodies as state collegial bodies or national regulatory commissions and does not stipulate the powers of the President of Ukraine and Verkhovna Rada of Ukraine in relation to these authorities. It should be stressed, that the Constitution of Ukraine includes the capable list of the powers of the President of Ukraine and Verkhovna Rada of Ukraine. It means that their powers cannot be established by other laws of Ukraine. Such official position was expressed in a number of the judgments of the Constitutional Court of Ukraine (Vashchenko, 2013). Thus, the status of national regulatory commissions should be improved by necessary amendments to the Constitution of Ukraine on powers of the President of Ukraine and the Verkhovna Rada of Ukraine.

It should be mentioned that the status of national regulatory commissions is considered as very similar to the status of the central banks. The issues of the independence of central banks related to a number of researches all over the world. In Ukraine, the National Bank of Ukraine has a status of a special central body of public governance according to Law of Ukraine "On National Bank of Ukraine" of 20 May 1999 No 679-XIV. It does not belong to any branch of power in Ukraine (Vashchenko, 2014).

The status of state collegial authorities has been enjoyed by a number of public bodies in Ukraine. However, not all of them can be considered as independent authorities that do not belong to any branch of power. For instance, the Accounting Chamber has the status of the state collegial authority in accordance with Law "On Accounting Chamber" of 2 July 2015 No 576-VIII. Despite the title "Accounting Chamber of Ukraine" presented at the official web site of the authority (http://www.ac-rada.gov.ua), the Accounting Chamber is not an independent public authority in Ukraine. In accordance with the Constitution of Ukraine (Art. 98) and the above mentioned Law "On Accounting Chamber" the Accounting Chamber shall execute the control over the revenues and expenditures of the State Budget of Ukraine on behalf of the Verkhovna Rada of Ukraine. Appointment and dismissal of the Head and other members of the Accounting Chamber belong to the powers of the Verkhovna Rada of Ukraine (Art. 85, part 1, indent 16). As referred to Article 1 of the above mentioned Law "On Accounting Chamber" the Accounting Chamber is accountable to the Verkhovna Rada of Ukraine and shall inform it about the results of its activity on a regular basis. Thus, the Accounting Chamber should be considered as a body of a parliamentary financial oversight in Ukraine. 
Another constitutional authority which enjoys the status of a state collegial authority is National Council of Television and Radio Broadcasting of Ukraine. This authority has a special place in the system of public bodies in Ukraine. Thus, the members of the authority shall be appointed and dismissed in equal parts by the Verkhovna Rada of Ukraine (Art. 85, part 1, indent 20) and the President of Ukraine (Art. 106, part 1, and indent 13). As referred to in Article 1 of the Law of Ukraine "On National Council of Television and Radio Broadcasting of Ukraine" (in the reduction of Law No 2461-IV of 3 March 2005) the National Council is the constitutional, permanent collegial authority aims to execute the supervision over the fulfilment of the laws of Ukraine in the field of television and radio broadcasting, as well as to conduct regulatory tasks defined by this Law. The National Council consists of 8 persons and has its apparatus. The authority is accountable to the Verkhovna Rada of Ukraine and to the President of Ukraine. The annual report of the National Council shall be presented to the both subjects of appointment before the February, 1. The consideration of such report can lead to the legal consequences stipulated by the Law mentioned above. Thus, the subject of appointment (namely, the Verkhovna Rada of Ukraine or the President of Ukraine) can use the right of early discharge of a member of the Council appointed by this subject in case of a negative assessment of his or her activity. The analysis of the law provisions on the legal status of the National Council leads to the conclusion that this authority does not belong to any branches of power.

Special place in the system of public authorities of Ukraine has been traditionally occupied by the Central Election Commission (hereinafter-CEC). CEC is a constitutional authority. The members of the CEC are appointed and dismissed by the Verkhovna Rada of Ukraine on a submission from the President of Ukraine (Art. 85, part 1, indent 21 of the Constitution of Ukraine). As referred to in Article 1 of Law of Ukraine "On Central Election Commission" (No 1932-IV of 30 June 2004) the CEC is a permanent collegial public authority responsible for the preparation and holding elections of the President of Ukraine, People's deputies of Ukraine, deputies of the Verkhovna Rada of the Autonomous Republic of Crimea, deputies of local self-government authorities (local councils), as well as the heads of such authorities, Ukrainian and local referenda. The commission acts independently from other public authorities, self-government bodies, their public officials. The guaranties of the CEC independence shall be stipulated by laws of Ukraine. Thus, the CEC does not belong to any branch of power in Ukraine. As to the accountability issues, one can conclude that there is only one type of the accountability of the CES clearly defined by the Law mentioned above - financial accountability. Thus, the CEC shall submit annual report on the use of the money from the State budget of Ukraine to the Accounting Council of Ukraine (Art. 36, part 3 of the Law). The provisions on early discharge of a member of the CES can be considered as part of the oversight mechanism prescribed by the Law. In particular, all members of the CEC can be early discharged by the Verkhovna Rada of Ukraine on a reasoned submission of the President of Ukraine (Art. 311 of the Law).

Considering mentioned above, there are several public authorities with the status of a state collegial authority in Ukraine. Some of them can be considered as independent authorities that do not belong to any branch of power, whereas others do not enjoy such 
an independent status. As to the independent authorities like national regulatory commissions, it is very important to amend the Constitution of Ukraine with the provisions regarding the special status of such authorities and to reach a balance between their independence and the accountability.

\section{Place of the certain law enforcement authorities in the system of public bodies of Ukraine}

Certain law enforcement authorities have a special place in the system of government in Ukraine. National anticorruption bureau of Ukraine, Security Service of Ukraine, and the public prosecutor's office are among them.

\subsection{National anticorruption bureau of Ukraine}

National anticorruption bureau is a relatively new public authority in Ukraine. As referred to in Article 1 of the special Law of Ukraine "On National anticorruption bureau" (No 1698-VII of 14 October 2014) the National anticorruption bureau (hereinafter - National Bureau) is a state law enforcement authority responsible for the prevention, detection, stop, investigation, and solution of corrupt violations in frames of its investigative jurisdiction, as well as prevention of new violations.

National bureau aims to prevent criminal corrupt violations made by higher public official responsible for the execution of functions of a state or local self-governance and dangerous for national security.

The legal framework of the National bureau has been established by the Law of Ukraine "On National anticorruption bureau of Ukraine" of 14 October 2014 No 1698VII. Analysis of the legal provisions leads to the opinion that the National bureau does not belong to any branch of power. Thus, it is established by the President of Ukraine. The Director of the National Bureau shall be appointed and dismissed by the President of Ukraine. In cases defined by the Law, the director can be dismissed by the Verkhovna Rada of Ukraine upon the proposal of not less than one third of people's deputies of Ukraine. Independence of the National bureau and its employees are defined among the main principles of its activity. However, it is necessary to reach the balance between the independence and the accountability of the authority. Provisions devoted to the control over the activity of the National bureau are stipulated by Article 26 of the Law mentioned above. Thus, the National bureau is accountable to the Committee of the Verkhovna Rada of Ukraine responsible for fight against corruption and the organized crime; it is answerable to the President of Ukraine, Verkhovna Rada of Ukraine, and the Cabinet of Ministers of Ukraine. It should be mentioned that the legal status of the National bureau faces the same problems as the legal status of national regulatory commissions characterized above in part of the constitutional legal aspects, since the Constitution of Ukraine does not include any provisions of the National bureau and the powers of the President of Ukraine and the Verkhovna Rada of Ukraine in relation to this authority.

\subsection{Public prosecutor's office}

The place of the public prosecutor's office in the system of public authorities is another interesting case in the light of the separation of powers in Ukraine. For a long time, the public prosecutor's office has been considered as an authority that does not belong to any branch of power, despite permanent discussions on this matter presented in the professional literature (Lapkin, 2015; Komzyuk, 2013). 
However, changes to the Constitution of Ukraine made by Law of Ukraine "On changes to the Constitution of Ukraine (regarding justice)" of 2 June 2016 No 1401-VIII resulted in a new wave of arguments pro and cons the independent place of the public prosecutor's office in the system of public authorities of Ukraine. According to the Law mentioned above the separate section devoted to the public prosecutor's office (section VII) was excluded from the Main Law of Ukraine and the Section VIII "Justice" was amended with the new Art. 1311 on the prosecutor's office. Based on these changes someone can sum up that the prosecutor's office currently belongs to the system of bodies of judicial power.

The European Commission for Democracy through Law (Venice Commission) in its Preliminary opinion on the proposed constitutional amendments regarding the judiciary of Ukraine of 24 July 2015 No 803/2015 stresses that a new system of prosecution is proposed as part of the judiciary (Venice Commission, 2015). Some researchers in Ukraine consider the constitutional amendments mentioned above as a placement of the prosecutor's office within the judicial branch of power (Torianyk, 2017).

M. Kosiuta pays attention that such changes do not mean that the prosecutor's office has been transformed into the body of justice (Kosiuta, 2017).

According to Law of Ukraine "On judiciary and the status of judges" of 2 June 2016 No 1402-VIII the judicial power in Ukraine is exercised by the independent and impartial courts established by law. It is realized by the judges and jury in accordance with law (Art. 1). As M. Tsurkan mentions, the judges are holders of judicial power; the latter consists of much more components, besides the notions of "judge" and "judiciary". It is also about preparation of judges, drafting laws on judges and judiciary, attestation, education, etc. (Veremko, 2017). Thus, in his opinion, the bar and the public prosecutor's office belong to the institute of judicial power. It should be noticed that the prosecutor's office has been considered as the law institute adjacent to the system of judiciary and judicial proceedings in the Strategy of the reforming the judiciary, judicial proceedings, and adjacent law institutes for 2015-2020 years approved by Decree of the President of Ukraine of 20 May 2015 No 276/2015. At the same time, M. Tsurkan stresses that the issue whether the public prosecutor's office belongs to the system of bodies of judicial power still needs to be addressed (Veremko, 2017).

M. Smokovych argues that the judicial power performs only one function - justice (Smokovych, 2012). Considering that only judges and jury can execute justice according to the Constitution of Ukraine and the Law of Ukraine on Judiciary and the status of judges, public prosecutor's office cannot be considered as part of the system of bodies of judicial branch of power.

As referred to in part 10 of Art. 131 of the Constitution of Ukraine according to the law bodies and institutions responsible for the encouragement of the selection of judges, prosecutors, their professional preparation, assessment, resolution of cases of their disciplinary liability, financial and organizational encouragement of courts shall be established in the system of justice. Supreme Council of Justice, Supreme qualification commission of judges of Ukraine, State judicial administration of Ukraine, and National school of judges of Ukraine are among such authorities and institutions in accordance with the Law of Ukraine on judiciary and status of judges. Thus, the public prosecutor's office has not defined as part of the system of justice. 
Therefore, the formal inclusion of the special article regarding the status of the public prosecutor's office in the section devoted to the justice cannot be considered as its integration in the system of bodies of judicial power. However, it should be mentioned that the existence of the separate section about the public prosecutor's office in the Constitution of Ukraine was considered as a strong argument for its separation from all traditional branches of power (Baranetskiy, 2015).

As to the foreign experience, it should be mentioned that there are different models regarding the place of the public prosecutor's office in the mechanism of separation of powers. A United Nations Office on Drugs and Crime and International Association in their Prosecutors Guide (2014) stress that the Guidelines on the Role of Prosecutors do not take a definitive stance on the issue of the formal independence of prosecutors from the executive branch, recognizing that different legal traditions and legal systems deal with the principle in different ways. The IAP Standards expressly provide that when prosecutorial discretion is permitted it should be exercised independently and be free from political interference (United Nations Office on Drugs and Crime, 2014).

Considering mentioned above, the question whether the public prosecutor's office belongs to the judicial branch of power or has a special place in the system of public authorities (some researchers argue the existence of such called controlling branch of power) is still open and future discussions are needed.

\subsection{Security Service of Ukraine}

Security Service of Ukraine (hereinafter - SSU) has a special place in the system of public authorities in Ukraine. It should be mentioned that the SSU belonged to the executive branch of power and had a status of body of executive power with a special status according to the Scheme of the organization and interaction of the central bodies of executive power (appendix to Decree of the President of Ukraine of 15 December 1999 No 1573/99). The SSU was excluded from the system of central bodies of executive power by Decree of the President of Ukraine of 28 April 2007 No 365/2007. The Constitutional Court of Ukraine in its Judgement of 20 October 2009 No 27-pп/2009 decided that indent 1 of Order of the Cabinet of Ministers of Ukraine of 22 April 2009 No 443-p "On repeal of the order of the SSU" was unconstitutional because the Cabinet of Minister of Ukraine, in frames of its competence, shall issue binding regulations and orders (Article 117, part 1 of the Constitution of Ukraine), can repeal acts of the ministries and other central bodies of executive power in whole or in part (Article 22, part 8 of the Law of Ukraine "On Cabinet of Ministers of Ukraine"); since the SSU was excluded from the organization scheme of central bodies of executive power, the Cabinet of Ministers of Ukraine did not have any power to repeal the acts of the SSU.

The legal framework of this authority is primarily represented by the Constitution of Ukraine and Law of Ukraine "On Security Service of Ukraine" of 25 March 1992 No 2229-XII. According to the Law mentioned above the SSU is a state authority of special purpose with law enforcement functions responsible for the protection of the state security of Ukraine. As referred to in the Constitution of Ukraine (Art. 85) the Chairperson of the SSU is appointed and dismissed by the Verkhovna Rada of Ukraine on the submission from the President of Ukraine. Security Service of Ukraine is subordinated to the President of Ukraine, accountable to the Verkhovna Rada of Ukraine and 
the President of Ukraine. The analysis of the provisions of the Constitution of Ukraine and other laws of Ukraine leads to the conclusion that the SSU does not belong to any traditional branch of power. Such vision of the status of the SSU has been represented in the scientific literature (Baranetskiy, 2015).

\section{National agency for quality assurance in higher education: a phenomena in the field of public administration in Ukraine}

The status of a permanent collegial body enjoyed by a brand-new institution in the area of higher education - National agency for quality assurance in higher education (hereinafter - Agency). The legal framework for the Agency primarily includes the Law of Ukraine "On higher education" of 1 July 2014 No 1556-VII and the regulations approved by the Cabinet of Ministers of Ukraine.

Agency consists of twenty three persons appointed by the Cabinet of Ministers of Ukraine on the basis of the competition commission established by the Cabinet of Ministers of Ukraine as an advisory body upon the results of the competitive selection, which is conducted in line with the principles of gender equality and industrial representation (Article 19, part 1). The head and deputy heads of the Agency shall be selected at the first meeting of the Agency for the term of three years. They shall be appointed and dismissed by the Cabinet of Ministers on the submission from the Agency (Article 18, part 5). Only the head and deputy heads work on the permanent basis.

Agency shall prepare and promulgate the report on the higher education quality in Ukraine, its correspondence to the requirements of the sustainable development of the society, the report on its activity, develops the proposals on legal encouragement of quality assurance for higher education, and submits these documents to the Verkhovna Rada of Ukraine, the President of Ukraine, the Cabinet of Ministers of Ukraine, and the higher education institutions for the discussion and adequate reaction (Article 18, part 2). However, the forms of such adequate reaction are not defined by the Law.

It should be mentioned that there are different thoughts among scholars concerning the legal status of the Agency. Some of them welcome the independent status of the Agency, while others think that the Agency lacks adequate level of independence. In particular, O. Melnychuk points out that Article 17 of the Law of Ukraine "On higher education" does not stipulate the independent and autonomous status of this important body in accordance with European standards and recommendations (Melnychuk, 2017). At the same time, O. Hrynkevych, O. Levytska mention that the establishment of the National agency for quality assurance in higher education - an independent permanent collegial authority responsible for the realization of the state policy in the area of higher education - was an important step in the development of national system of education in Ukraine (Hrynkevych, Levytska, 2017).

However, the main problem is that the Agency does not have a status of a public authority at all. As referred to in Article 17 of the Law mentioned above the Agency is a permanent collegial authority responsible for the realization of the state policy in the area of higher education quality assurance. But the Law lacks the term "state" or "public" in relation to this authority. Still, based on the formulation "responsible for the realization of state policy" one can presume that this institution has a status of a state authority. However, the Agency does not have this status in practice. According to the Unified 
state register of legal entities, natural persons - entrepreneurs, and public organizations the Agency has an organizational legal form of a public organization (foundation, institution) which differs from the organizational legal form of a public authority. The same organizational legal form has, for instance, the National Academy of Science of Ukraine; however, the latter is not responsible for the realization of the state policy. According to the Law of Ukraine "On higher education" the Agency plays a very important role in the higher education area. In particular, the Agency shall conduct the institutional accreditation of higher educational institutions, the accreditation of the study programmes, the accreditation of the specialized scientific councils and controls their activity (Article 18, part 1, indents 3, 6, 9). Moreover, in certain cases prescribed by this Law the acts of Ministry of education and science of Ukraine (hereinafter - MESU) (in particular, on standards of educational activity and higher education - Article 9, part 3; Article 10, part 6: Article 13, part 1, indent 16) shall be approved only upon the consideration with the Agency. In such cases the MESU can make an autonomous decision if only the Agency has not executed its powers in terms defined by the legislation (Article 13, part 6). Thus, the Law uses the following terms in relation to the Agency as the "body", "powers", empowers the Agency to realize the state policy, to consider the certain decisions of the MESU, to control the activity of the specialized scientific councils, but does not define it as a public authority.

It should be mentioned that the issue of the legal status of the Agency has been attracted the attention of the professionals since the development and consideration of the draft law "On higher education". The opinion on draft Law "On higher education" (register No 1187-2) of the Main scientific and expert department of the Verkhovna Rada of Ukraine has included a number of remarks regarding the legal status of the Agency. In particular, it was mentioned that the status of the Agency is not clear since the institution which does not have a status of a public authority is empowered to realize certain functions of the central body of executive power in the area of education and science (the Main scientific and expert department of the Verkhovna Rada of Ukraine, 2013).

Also it is pointed out that the provisions of the draft law regarding the powers of the Verkhovna Rada and the President of Ukraine in relation to the report of the Agency are not in line with the provisions of the Constitution of Ukraine, since it includes the exhaustive list of their powers. The Main legal department of the Verkhovna Rada of Ukraine while analyzing the draft Law "On higher education" (register No 1187-2) warned that the execution of the powers of the public authority - central body of executive power in the area of education and science depends on the activity of advisory authority (National agency) which is not in line with the constitutional model of the organization of power (the Main legal department of the Verkhovna Rada of Ukraine, 2013).

V. Bakhrushyn pays attention to the issue of the legal status of the Agency and suggests gradual separation of the certain functions from the state and establishment of efficient mechanisms of nongovernmental quality assurance of higher education, similar to other European states (Bakhrushyn, 2016).

To sum up, the legal status of the Agency needs to be improved. Therefore, there is a need for a comprehensive legal research on the certain issue. 


\section{Conclusions and recommendations}

Considering mentioned above, the principle of separation of power is constitutionalized in Ukraine and respected in the legal doctrine; however, the recent reforms in the system of public authorities in Ukraine and modern research trends require the revision of the traditional approaches to its understanding.

The Constitution of Ukraine stipulates that the power is Ukraine shall be conducted on the basis of it separation into legislative, executive, and judicial. However, as in many countries in the world, the principle "one branch - one function" is impossible to sustain.

The system of public authorities in Ukraine has been characterized by the high level of diversity. In particular, multifunctionality of executive power requires a huge number of public institutions carry out different functions of executive power. As was explored in this paper, not all of such institutions belong to the system of bodies of executive power. For example, there are institutions that, to some extent, combine the functions of all three traditional branches of power - national regulatory commissions; whereas others even do not have a status of a public authority (e. g, National agency for quality assurance in higher education).

There are public authorities that formally do not belong to any branch of power, in particular, National Bank of Ukraine, national regulatory commissions, Central Election Commission. Certain law enforcement authorities like the Security Service of Ukraine and National Anticorruption Bureau of Ukraine also have a special place in the system of public authorities and do not belong to any branch of power. As to the public prosecutor's office, the recent changes to the Constitution of Ukraine leaded to the waves of serious discussions about its place in the system of public authorities and the role in the mechanism of the separation of power. Some scholars even consider the separation of the forth branch of power - control branch of power.

Addressing the issue about the compliance of the system of public authorities in Ukraine with the constitutional principle of the separation of powers, it is suggested to think about the distinction of the following categories: a branch of power and a branch of government, as functional and institutional elements of the principle of the separation of powers. According to this approach there would be three classical branches of powerlegislative, executive and judicial separated on the functional basis that can be distributed among different branches of government. In this case, one can argue the separation of the control branch of government or regulatory branch of government. Some mixture of the functions within the bodies of the classical branches of power can be also possible, following the approach mentioned above. For example, yet the legislative power will remain as the core function of the body of legislative power, the latter can carry out some functions of another branch of power (for instance, of executive branch of power - in case of internal organizational activity).

Despite of the different theoretical approaches to the understanding the principle of the separation of powers, the importance to encourage the efficient mechanisms of accountability and responsibility of the all public authorities is doubtless.

In case of Ukraine, it is very important to enhance the legal status of public institutions analyzed in this paper, in particular, in part of their governmental regimes. As to the public authorities that do not belong to any branch of power as national regulatory commissions and National anticorruption bureau of Ukraine it is necessary to amend 
the Constitution of Ukraine with the provisions regarding such authorities, in particular, with the powers of the President of Ukraine and the Verkhovna Rada of Ukraine in relation to this authorities.

\section{Bibliography:}

1. Kavanagh A. The Constitutional Separation of Powers. URL: https://www.law.ox.ac.uk/ sites/files/oxlaw/ak_separation_of_powers_philfounds_book.pdf (date of request: 06.12.2018).

2. Bignami F. Comparative Administrative Law. URL: https://scholarship.law.gwu.edu/cgi/ viewcontent.cgi?article $=1158 \&$ context $=$ faculty_publications (date of request: 06.12.2018).

3. European Commission for Democracy through Law (Venice Commission). Preliminary opinion on the proposed constitutional amendments regarding the judiciary of Ukraine of 24 July 2015 № 803/2015. URL: https://www.venice.coe.int/webforms/documents/default.aspx?pdffile $=$ CDL-PI(2015)016-e (date of request: 06.12.2018).

4. Toppetwien B. Separation of powers and the status of administrative review. AIAL Forum. 1999. № 20. P. 32-45. URL: http://classic.austlii.edu.au/au/journals/AIAdminLawF/1999/4. pdf (date of request: 06.12.2018).

5. Торяник О.Ю. Компетенція органів прокуратури України як основи ії конституційно-правового статусу. Порівняльно-аналітичне право. 2017. № 3. C. 64-66. URL: http://www.pap.in.ua/3_2017/18.pdf (дата звернення: 06.12.2018).

6. UNODC. The Status and Role of Prosecutors: United Nations Office on Drugs and Crime and International Association of Prosecutors Guide. New York, 2014. URL: https://www.unodc.org/documents/justice-and-prison-reform/HB_role_and_status_ prosecutors_14-05222_Ebook.pdf (date of request: 06.12.2018).

7. Waldron J. Separation of Powers in Thought and Practice. Boston College Law Review. 2013. Vol. 54. Iss. 2. P. 433-468. URL: http://lawdigitalcommons.bc.edu/bclr/vol54/iss2/2 (date of request: 06.12.2018).

8. Баранецький Р.Ф. Щодо статусу служби безпеки України як органу державної влади. Юридична наука. 2015. № 2. С. 22-27.

9. Бахрушин В.С. Чи потрібно Україні НАЗЯВО? URL: http://education-ua.org/ua/ articles/736-chi-potribno-ukrajini-nazyavo (дата звернення: 06.12.2018).

10. Ващенко Ю.В. Адміністративно-правовий статус енергетичного регулятора в Україні: сучасний стан та перспективи реформування у контексті європейської інтеграції: монографія. К.: Юрінком Інтер, 2015. 288 с.

11. Ващенко Ю.В. Центральні органи виконавчої влади зі спеціальним статусом: проблеми правової природи та перспективи реформування. Адміністративне право і процес. 2014. № 3(9). С. 122-141.

12. Веремко В.Г. Суддя ВАСУ у відставці Михайло Цуркан: «ВРП може створювати, забезпечувати суддям відчуття захищеності, а не просто захищати»: інтерв'ю. Закон і бізнес. 2017. № 8(1306). URL: https://zib.com.ua/ua/print/127726-suddya_vasu_u_vidstavci_mihaylo_ curkan_vrp_mozhe_stvoryuvati.html (дата звернення: 06.12.2018).

13. Висновок Головного науково-експертного управління Верховної Ради України на проект Закону України «Про вищу освіту» від 21 січня 2013 р. № 1187-2. URL: http://w1.c1.rada.gov.ua/pls/zweb2/webproc4_1?pf3511=45512 (дата звернення: 06.12.2018).

14. Гринькевич О.С., Левицька О.О. Інституційне середовище забезпечення якості системи вищої освіти: міжнародний і національний аспекти. Науковий вісник Ужгородського національного університету. Серія «Міжнародні економічні відносини та світове господарство». 2017. Вип. 15. Ч. 1. С. 84-90. URL: http://www.visnyk-econom.uzhnu.uz.ua/ archive/15_1_2017ua/21.pdf (дата звернення: 06.12.2018). 
15. Зауваження до проекту Закону України «Про вищу освіту» від 21 січня 2013 р. № 1187-2. URL: http://w1.c1.rada.gov.ua/pls/zweb2/webproc4_1?pf3511=45512 (дата звернення: 06.12.2018).

16. Комзюк А.Т. Місце органів прокуратури України в сучасній системі гілок влади. Форум права. 2013. № 2. С. 230-234. URL: http://nbuv.gov.ua/UJRN/FP_index. htm_2013_2_35 (дата звернення: 06.12.2018).

17. Косюта М.В. Роль і місце прокуратури України в системі поділу влади. Науковий часопис Національної академії прокуратури України. 2017. № 4. С. 101-113. URL: http://www.chasopysnapu.gp.gov.ua/ua/pdf/4-2017/kosuta.pdf (дата звернення: 06.12.2018).

18. Лапкін А.В. Прокуратура в системі судової влади. Право України. 2015. № 9. C. 164-171. URL: http://dspace.nlu.edu.ua/bitstream/123456789/10767/1/Lapkin_164-171.pdf (дата звернення: 06.12.2018).

19. Мельничук О.Ф. Правові засади діяльності Національного агентства із забезпечення якості вищої освіти в умовах євроінтеграції. Публічне право. 2017. № 1(25). С. 67-72.

20. Смокович М.І. Судова влада: місце в суспільстві та судовий контроль. Юридична Україна. 2012. № 10. С. 99-107.

21. Шаповал В.М. Виконавча влада та конституційна модель розподілу влад в Україні. Науковий вісник Чернівецького університету. 2012. Вип. 641: Правознавство. С. 32-39.

22. Шмідт-Ассманн Е. Загальне адміністративне право як ідея врегулювання: основні засади та завдання систематики адміністративного права / пер. 3 нім.: Г.О. Рижков, І.В. Сойко, А.М. Баканов; відп. ред. О.М. Сироїд. 2-ге вид., перероб. та доп. К.: К. І. С., 2009. 552 c.

\section{References:}

1. Kavanagh, A. (2016). The Constitutional Separation of Powers. Retrieved from: https://www.law.ox.ac.uk/sites/files/oxlaw/ak_separation_of_powers_philfounds_book.pdf.

2. Bignami, F. (2012). Comparative Administrative Law. Retrieved from: https://scholarship.law.gwu.edu/cgi/viewcontent.cgi?article=1158\&context=faculty_publications.

3. Venice Commission (2015). Preliminary opinion on the proposed constitutional amendments regarding the judiciary of Ukraine of 24 July 2015 № 803/2015. Retrieved from: https://www.venice.coe.int/webforms/documents/default.aspx?pdffile=CDL-PI(2015)016-e.

4. Toppetwien, B. (1999). Separation of powers and the status of administrative review. AIAL Forum, no. 20, pp. 32-45. Retrieved from: http://classic.austlii.edu.au/au/journals/ AIAdminLawF/1999/4.pdf.

5. Torianyk, O.Yu. (2017). Kompetentsiia orhaniv prokuratury Ukrainy yak osnovy yii konstytutsiino-pravovoho statusu [Competence of the prosecutor's office of Ukraine as the basis of its constitutional and legal status]. Porivnialno-analitychne pravo, no. 3, pp. 64-66. Retrieved from: http://www.pap.in.ua/3_2017/18.pdf.

6. UNODC (2014). The Status and Role of Prosecutors: United Nations Office on Drugs and Crime and International Association of Prosecutors Guide. New York. Retrieved from: https://www. unodc.org/documents/justice-and-prison-reform/HB_role_and_status_prosecutors_14-05222_ Ebook.pdf.

7. Waldron, J. (2013). Separation of Powers in Thought and Practice. Boston College Law Review, vol. 54, iss. 2, pp. 433-468. Retrieved from: http://lawdigitalcommons.bc.edu/bclr/vol54/ iss $2 / 2$.

8. Baranetskyi, R.F. (2015). Shchodo statusu sluzhby bezpeky Ukrainy yak orhanu derzhavnoi vlady [As to the status of the security service of Ukraine as a state authority]. Yurydychna nauka, no. 2, pp. 22-27. 
9. Bakhrushyn, V.Ye. (2016). Chy potribno Ukraini NAZIaVO? [Does the NAQAHE require Ukraine?]. Retrieved from: http://education-ua.org/ua/articles/736-chi-potribno-ukrajininazyavo.

10. Vashchenko, Yu.V. (2015). Administratyvno-pravovyi status enerhetychnoho rehuliatora v Ukraini: suchasnyi stan ta perspektyvy reformuvannia u konteksti yevropeiskoi intehratsii: monohrafiia [The administrative and legal status of the energy regulator in Ukraine: the current state and prospects of reform in the context of European integration: monograph]. Kyiv: Yurinkom Inter. [in Ukrainian].

11. Vashchenko, Yu.V. (2014). Tsentralni orhany vykonavchoi vlady zi spetsialnym statusom: problemy pravovoi pryrody ta perspektyvy reformuvannia [Central bodies of executive power with a special status: problems of legal nature and prospects of reform]. Administratyvne pravo i protses, no. 3(9), pp. 122-141.

12. Veremko, V.H. (2017). Suddia VASU u vidstavtsi Mykhailo Tsurkan: "VRP mozhe stvoriuvaty, zabezpechuvaty suddiam vidchuttia zakhyshchenosti, a ne prosto zakhyshchaty": interviu [Higher Administrative Court of Ukraine judge emeritus Mykhailo Tsurkan: "SCJ can establish, encourage the sense of security for judges, not just protect": interviews]. Zakon i biznes, no. 8(1306). Retrieved from: https://zib.com.ua/ua/print/127726-suddya_vasu_u_vidstavci_ mihaylo_curkan_vrp_mozhe_stvoryuvati.html.

13. The Main Scientific and Expert Department of the Verkhovna Rada of Ukraine (2013). Vysnovok na proekt Zakonu Ukrainy "Pro vyshchu osvitu" vid 21 sichnia 2013 r. № 1187-2 [Conclusion on the Draft Law of Ukraine “On Higher Education” dated January 21, 2013. No. 1187-2]. Retrieved from: http://w1.c1.rada.gov.ua/pls/zweb2/webproc4_1?pf3511=45512.

14. Hrynkevych, O.S., Levytska, O.O. (2017). Instytutsiine seredovyshche zabezpechennia yakosti systemy vyshchoi osvity: mizhnarodnyi i natsionalnyi aspekty [Institutional environment for ensuring the quality of the higher education system: international and national aspects]. Naukovyi visnyk Uzhhorodskoho natsionalnoho universytetu. Seriia "Mizhnarodni ekonomichni vidnosyny ta svitove hospodarstvo", iss. 15, part 1, pp. 84-90. Retrieved from: http://www. visnyk-econom.uzhnu.uz.ua/archive/15_1_2017ua/21.pdf.

15. The main legal department of the Verkhovna Rada of Ukraine (2013). Zauvazhennia do proektu Zakonu Ukrainy "Pro vyshchu osvitu” vid 21 sichnia 2013 r. № 1187-2 [Comments on the draft Law of Ukraine "On Higher Education" dated January 21, 2013, No. 1187-2]. Retrieved from: http://w1.c1.rada.gov.ua/pls/zweb2/webproc4_1?pf3511=45512.

16. Komziuk, A.T. (2013). Mistse orhaniv prokuratury Ukrainy v suchasnii systemi hilok vlady [Place of the prosecutor's office in the modern system of branches of power]. Forum prava, no. 2, pp. 230-234. Retrieved from: http://nbuv.gov.ua/UJRN/FP_index.htm_2013_2_35.

17. Kosiuta, M.V. (2017). Rol i mistse prokuratury Ukrainy v systemi podilu vlady [The role and place of the prosecutor's office in the system of separation of powers]. Naukovyi chasopys Natsionalnoi akademii prokuratury Ukrainy, no. 4, pp. 101-113. Retrieved from: http://www.chasopysnapu.gp.gov.ua/ua/pdf/4-2017/kosuta.pdf.

18. Lapkin, A.V. (2015). Prokuratura v systemi sudovoi vlady [Prosecutor's Office in the judicial system]. Pravo Ukrainy, no. 9, pp. 164-171. Retrieved from: http://dspace.nlu.edu.ua/ bitstream/123456789/10767/1/Lapkin_164-171.pdf.

19. Melnychuk, O.F. (2017). Pravovi zasady diialnosti Natsionalnoho ahentstva iz zabezpechennia yakosti vyshchoi osvity v umovakh yevrointehratsii [Legal basis of the National Agency for the Quality Assurance of Higher Education in the context of European Integration]. Publichne pravo, no. 1(25), pp. 67-72.

20. Smokovych, M.I. (2012). Sudova vlada: mistse v suspilstvi ta sudovyi kontrol [Judiciary: place in society and judicial control]. Yurydychna Ukraina, no. 10, pp. 99-107. 
21. Shapoval, V.M. (2012). Vykonavcha vlada ta konstytutsiina model rozpodilu vlad v Ukraini [Executive power and constitutional model of the distribution of power in Ukraine]. Naukovyi visnyk Chernivetskoho universytetu, iss. 641: Pravoznavstvo, pp. 32-39.

22. Shmidt-Assmann, E. (2009). Zahalne administratyvne pravo yak ideia vrehuliuvannia: osnovni zasady ta zavdannia systematyky administratyvnoho prava [General administrative law as an idea of regulation: the main principles and objectives of the taxonomy of administrative law]. Kyiv: K. I. S. [in Ukrainian].

\title{
РОЗПОДІЛ ВЛАД В УКРАЇНІ: ВИКЛИКИ ТА СПОСОБИ ВИРІШЕННЯ 3 ПЕРСПЕКТИВИ АДМІНІСТРАТИВНОГО ПРАВА
}

\author{
Юлія Ващенко, \\ професор кафедри адміністративного права юридичного факультету \\ Київського національного університету імені Тараса Шевченка, \\ доктор юридичних наук, доцент \\ orcid.org/0000-0002-5252-1997 \\ y_vashchenko@univ.kiev.ua
}

Розподіл влад розглядається як один з основних стрижнів демократичної держави. Існують різні наукові підходи до змісту й ролі розподілу влад у демократичному державному апараті: від «чистої», традииійної теорії чіткого розподілу влад до гнучкого сучасного підходу. В Україні принцип поділу влади закріплений у Конституиії України. Деякі фахівиі вважають, щьо в Україні можуть утворюватися лише органи законодавчої, виконавчої та судової влади, тоді як інші обтрунтовують існування незалежних органів, які не належать до жодної з гілок влади.

Мета. Статтю спрямовано на визначення проблем дотримання принципу розподілу влади в Україні щзодо системи публічної адміністрації та окресленню можлливих иляхів удосконалення правового статусу суб'єктів публічної адміністрації.

Методи. Досягненню мети дослідження сприяло використання методів наукового пізнання, зокрема методу логічного аналізу, системно-структурного та системнофункиіонального методів.

Результати. Рекомендовано розрізняти гілку влади та гілку (галузь) державного апарату як функціональний та інституційний елементи принципу розподілу влад.

Висновки. Зроблено висновок про існування державних органів, які не належать до жодної з гілок влади, серед яких, зокрема, Національний банк України, національні комісії, щзо здійснюють державне регулювання в певних сферах економіки, Центральна виборча комісія, Служба безпеки Украӥни, Начіональне антикорупџійне бюро України. Незважаючи на нещодавні зміни до Конституції України, питання щуодо місчя в системі державного апарату органів прокуратури залишається. Зроблено висновок про те, щу Національне агентство із забезпечення якості вищої освіти не є держсавним органом, хоча й здійснює певні функції иентрального органу виконавчої влади.

Стосовно національних регуляторних комісій та Національного антикорупиійного бюро Украӥни зроблено висновок про необхідність доповнення Конституції Украӥни положеннями щьдо зазначених органів, зокрема, повноваженнями Президента Украӥни та Верховної Ради України щэодо їх формування й управлінських режсиів.

Ключові слова: розподіл влад, виконавча гілка влади, гілка (галузь) державного апарату, публічна адміністрація, незалежні регуляторні органи, четверта гілка влади. 